\title{
DIFFERENT PERCEPTIONS OF CONCERN FACTORS FOR STRATEGIC INVESTMENT OF THE PRIVATE SECTOR IN PUBLIC-PRIVATE PARTNERSHIP TRANSPORTATION PROJECTS
}

\author{
Do Tien $\mathrm{Sy}^{1}$, Veerasak Likhitruangsilp ${ }^{2}$, Masamitsu Onishi ${ }^{3}$, and PhongThanh Nguyen ${ }^{4}$ \\ ${ }^{1}$ Department of Civil Engineering, Chulalongkorn University, Bangkok, \\ Thailand, Tel: +668 5136 5655, e-mail: Sy.dotien@yahoo.com \\ ${ }^{2}$ Department of Civil Engineering, Chulalongkorn University, Bangkok, \\ Thailand, Tel: +668 0557 8257, e-mail:Veerasak.L@chula.ac.th \\ ${ }^{3}$ Department of Planning and Management Systems, Kyoto University, Kyoto, \\ Japan, Tel: +81 75383 3224, e-mail: onishi.masamitsu.7e@kyoto-u.ac.jp \\ ${ }^{4}$ Department of Project Management, Ho Chi Minh City Open University, Ho Chi Minh City, \\ Vietnam, Tel: +849 0595 7580, e-mail: ntphong1711@yahoo.com
}

Received Date: March 4, 2016

\begin{abstract}
This paper identifies the concern factors of private investors associated with Public-Private Partnership (PPP) transportation projects in Vietnam. The concern factors are incorporated into four main groups: (1) company profile; (2) finance; (3) opportunities; and (4) risk perceptions. The paper examines the different perceptions by the public and private sectors about these concern factors adopted by experienced professionals related to PPP transportation projects. Based on a questionnaire survey in Vietnam, the most concern factors of private investors are their own capacity, demand issues, legal and political risks, long-term income, and financial sources issues of the PPP project. Moreover, five factors that represent the significant differences between the private and public sectors including political risks, enhancement of company's strength in its industry, construction risks, demand issues, and financial viability of the company are also discovered. Addressing the different perceptions is indispensable to ensure the public sector can establish necessary policies that appeal to both domestic and foreign private investors. The paper at the same time hopes to provide some of lessons for the private sector.
\end{abstract}

Keywords: Concern factors, Different perceptions, Investment, Public-private partnership, Transportation, Vietnam

\section{Introduction}

Public-Private Partnership (PPP) have emerged as one of the main approaches to developing infrastructure systems in recent years. If it was established and strictly managed, a PPP can bring many benefits for the public sector such as: adding missing financial capital due to the large cost of infrastructure projects; transferring risks from the public sector to the private sector; and increasing the "value for money" for infrastructure services by providing more efficient, cost reduction, and good services. However, the PPP experience of Vietnamese government was still insufficient. For instance, many PPP projects must hold on or canceled because of many reasons: wide expectation gaps among the public and private sectors, lack of clarity of the commitments and policies of the government, the complex process of approvals and permits, inadequate legal framework, poor risk management, underdevelopment financial 
market, lack of transparency and lack of competition [1]. In Vietnam, it can be said that investment environment currently cannot attract private investors to promote to PPP transportation projects due to a lot of issues, such as legal issues, government incentives problems, financial issues, pre-construction issues (i.e. feasibility studies, land acquisition/ compensation), macroeconomics [2,3]. Therefore, in order to attract the participation of investment capitals from the private sector, the public sector have to understand and answer the question "what are expectation or concern factors of the private sector?"

Generally, when investing in any PPP project,private investorsmight have to focus on their major expectations about investment environment, government's incentive policies, the feasibility, investment period, and profitability of the PPP project. Finance issues, risks, opportunities matters are also significant problems that need to be evaluated before their investment in PPP projects. Indeed, research by Sader [4] has identified some potential investors' expectations including operating profitably, finding trustworthy partners, diversifying risk, reducing uncertainty, stability legal framework and avoiding contingent liabilities. Moreover, study by Demirag et al. [5] has found some financial and non-financial criteria that affecting the decisions to participate in a private finance initiative (PFI) project. The most critical financial criteriawere interest rate of return and return on equity, whereas reputation and familiar relationships with industry was the most common cited non-financial criteria. Furthermore, private investors have opportunities to penetrate new international markets for their own business [6, 7] when they plan to invest in PPP projects in some foreign countries. Therefore, if overall expectation conditions appear to be advantageous, private investors would then be quite willing to invest. Besides, the understanding of expectations of the private sector will help the government or the public sector to enhance investment environment to attract the participation of private investors. Moreover, failing to address the main expectations of stakeholders involved has resulted in many project failures [8]. The objectives of this paper are to identify and assess the critical concern factors of private investors when investing in PPP transportation projects, and to realize the significant differences perceptions between the public and private sectors.

\section{Concern Factors of Private Investors}

Several attempts have been made to assess the concerns or expectations of private investors in PPP projects (e.g., Kwak et al. [1]; Demirag et al. [5]; Ozdoganm and Birgonul [6]; Grimsey and Lewis [9];Schaufelberger and Wipadapisut [10]; Cuttaree [11]; and Ng et al. [12]). However, most of these studies have just concentrated on a single concern factor or a limited number of them. In order to understand the perceptions of private investors into PPP projects efficiently, concern factors have to be identified, and categorized. Research of Demirag et al. [5] focused on the factors that cause the financiers to take part in a PFI projects. These factors were divided into two main groups: financial criteria and non-financial criteria. Financial criteria are the financial factors that concerned by financiers, such as internal rate of return (IRR), return on equity (RoE), equity payback period, availability of debt finance, whereas the non-financial criteria related to financiers' themselves, including reputation, relationships, etc. To classify concern factors based on their sources and hierarchical structure was common method in considering the important level of expectation or concern factors. It is proposed that the concern factors be categorized into four main categories, namely (1) company profile; (2) finance; (3) opportunities; and (4) risk perceptions as shown in Figure 1. 


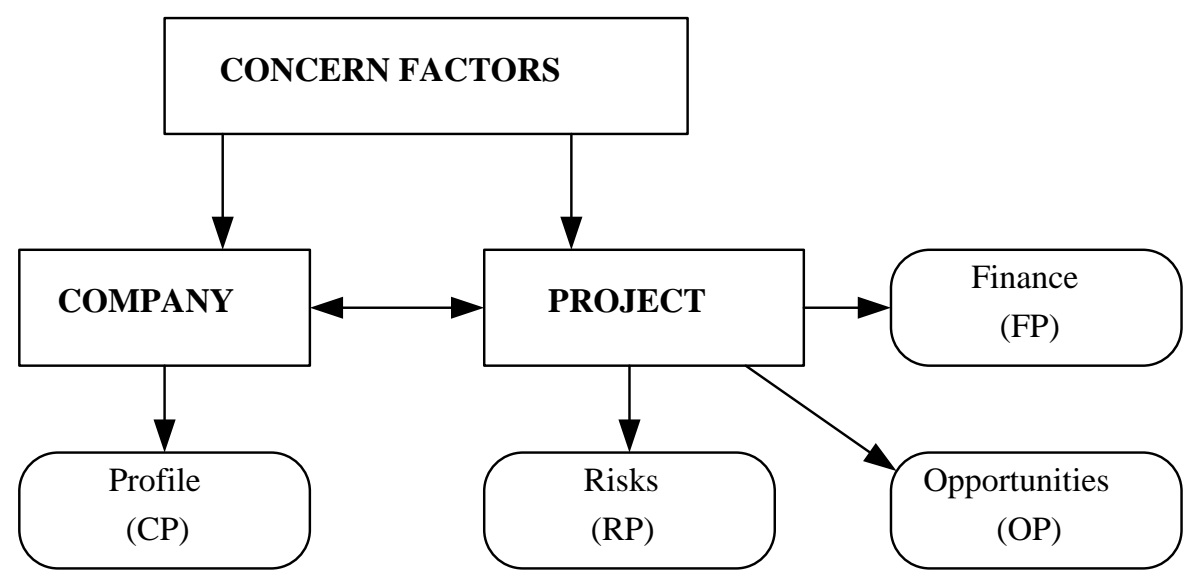

Figure 1. Concern factors groups of private investors

\section{Category 1 - Company Profile}

Company profile concern factors are issues related to capabilities of private investors, such as management capacity, financial viability, resources and experiences of their partners in consortium (partners join together to establish specific purpose vehicle or concession company). As we know, the financial and technical strength of the consortium was regarded as the most important critical success factors in PPP projects [13]. In addition, the ability of private investors to arrange flexible and attractive financial package is a very important factor leading to the success in winning the tendering process in BOT projects in China of consortium $[1,14]$. Besides, in order to increase the success of PPP projects, private investors often combined together into group of multidisciplinary companies. Actually, in this consortium, all participating entities have to work together, make decisions collectively, sharing risks and responsibilities, getting profits, and work together to solve the conflict situation [1]. Therefore, companies with good management, finance, as well as abundant resources are considered to cooperate. Additionally, experiences in various areas or fields of the consortium can reduce the risk related to future investment projects, meet contractual commitments in an effective manner as well as gain profit necessary. Finally, concern factors related to the company profile can summarize into four main factors, namely, management capacity of the company (CP1), financial viability of the company (CP2), the company's resources about labor, machinery, engineering (CP3), and the company's experience with same project before (see Table 1).

\section{Category 2 - Finance of PPP Projects}

Regarding the PPP projects, private investors do care about finance issues of these projects. For instance, return on equity (ROE), long-term income, cash flow, financing sources, tariff, and demand are some of issues were concerned by private investors (see Table 1). The total investments of PPP projects are so large that private investors must prepare appropriate financing policies. Due to research by Kwak et al. [1], early involvement with the financial institutions was one of the most important tasks to enhance the ability to win the tender of PPP project. Revenue risk was another concern of the private sector when they make decision to participate in PPP projects [9]. Revenues or incomes of PPP projects are affected by many factors such as return on equity, long term income, and cash flows of these projects [1,5,9]. Toll/tariff levels need to be adequate for private's point of view to compensate investors and 
lenders [14]. However, this toll/tariff levels should not rise too high, which will be consistent with the affordability of users or customers.

Table 1. Concern Factors of Private Investors

\begin{tabular}{|c|c|c|c|}
\hline No. & Code & Factors & Literature Review \\
\hline I & CP & COMPANY PROFILE & \\
\hline 1 & CP1 & $\begin{array}{l}\text { Management capacity of the } \\
\text { company }\end{array}$ & $\begin{array}{l}\text { Tiong [13], Sader[4], Qiao et al. [14], Ahadzi and } \\
\text { Bowles [15], Nisar[16], Kwak et al.[1], Mustajab } \\
\text { [17] }\end{array}$ \\
\hline 2 & СР2 & $\begin{array}{l}\text { Financial viability of the } \\
\text { company }\end{array}$ & Kwak et al.[1] \\
\hline 3 & СР3 & $\begin{array}{l}\text { The company's resources } \\
\text { about labor, machinery, } \\
\text { engineering }\end{array}$ & $\begin{array}{l}\text { Kwak et al.[1], Sader [4], Tiong [13], Qiao et al. } \\
\text { [14], Ahadzi and Bowles [15], Nisar[16], } \\
\text { Mustajab [17] }\end{array}$ \\
\hline 4 & CP4 & $\begin{array}{l}\text { The company's experience } \\
\text { with same project before }\end{array}$ & Kwak et al.[1], Demirag et al. [5] \\
\hline II & FP & $\begin{array}{lll}\text { FINANCE } & \text { OF } & \text { PPP } \\
\text { PROJECTS } & & \end{array}$ & \\
\hline 1 & FP1 & Return on equity investment & Demirag et al. [5] \\
\hline 2 & FP2 & $\begin{array}{l}\text { Possibility of long-term } \\
\text { income }\end{array}$ & Grimsey and Lewis [9] \\
\hline 3 & FP3 & Project cash flows & Kwak et al.[1] \\
\hline 4 & FP4 & $\begin{array}{l}\text { Availability of financing } \\
\text { sources }\end{array}$ & Kwak et al.[1], Demirag et al. [5] \\
\hline 5 & FP5 & Tax/tariff issues & $\begin{array}{l}\text { Demirag et al. [5], Thomas et al. [18], Thomas et } \\
\text { al. [19] }\end{array}$ \\
\hline 6 & FP6 & Demand issues & Valentine [20], Ashuri et al. [21] \\
\hline III & $\mathbf{O P}$ & $\begin{array}{l}\text { OPPORTUNITIES OF PPP } \\
\text { PROJECTS }\end{array}$ & \\
\hline 1 & OP1 & Assess/seek to new markets & Alquier et al. [7] \\
\hline 2 & OP2 & $\begin{array}{l}\text { Enhancing relationship with } \\
\text { lenders }\end{array}$ & Demirag et al. [5] \\
\hline 3 & OP3 & $\begin{array}{l}\text { Enhancing relationship with } \\
\text { contractors, } \\
\text { management, or operator } \\
\text { companies }\end{array}$ & Demirag et al. [5] \\
\hline 4 & OP4 & $\begin{array}{l}\text { Enhancement of company's } \\
\text { strength in its industry }\end{array}$ & Demirag et al. [5] \\
\hline 5 & OP5 & Value of image to other clients & Demirag et al. [5] \\
\hline 6 & OP6 & Need for work & Alquier et al. [7] \\
\hline IV & $\mathbf{R P}$ & RISK OF PPP PROJECTS & \\
\hline 1 & RP1 & Political risks & Kwak et al.[1], Ng et al. [12], Chan et al. [22] \\
\hline 2 & RP2 & Legal risks & $\begin{array}{l}\text { Cuttaree [11], Qiao et al. [14], Mustajab [17], Dias } \\
\text { and Ioannou [23], Zhang and Wang [24],, Ward } \\
\text { and Sussman [25] }\end{array}$ \\
\hline
\end{tabular}




\begin{tabular}{|c|c|c|c|}
\hline No. & Code & Factors & $\begin{array}{c}\text { Literature Review } \\
\end{array}$ \\
\hline 3 & RP3 & Commercial risks & $\begin{array}{l}\text { Toan and Ozawa [26], Xu et al. [27], Karim [28], } \\
\text { Ke et al. [29], Hwang et al. [30], Ezeldin and } \\
\text { Badran[31] }\end{array}$ \\
\hline 4 & RP4 & Design and procurement risks & $\begin{array}{l}\text { Xu et al. [27], Karim [28], Ke et al. [29], Hwang } \\
\text { et al. [30] }\end{array}$ \\
\hline 5 & RP5 & Construction risks & $\begin{array}{l}\text { Toan and Ozawa [26], Xu et al. [27], Karim [28], } \\
\text { Ke et al. [29], Hwang et al. [30]; Ezeldin and } \\
\text { Badran [31], Iyer and Sagheer [32] }\end{array}$ \\
\hline 6 & RP6 & Operation risks & $\begin{array}{l}\text { Thomas et al. [18], Dias and Ioannou[23],Toan } \\
\text { and Ozawa [26], Xu et al. [27] }\end{array}$ \\
\hline
\end{tabular}

\section{Category 3 - Opportunities of PPP Projects}

Ward and Sussman [25], and Cuttaree [11] argued that the primary objective of private investors seek to profit from provision of services. Besides, the private sector also would like to have more opportunities in new market, especially for foreign investors [6]. Moreover, private investors sometimes could accept a lower profit contribution with a greater probability of tender winning [7]. Besides, they might accept to participate some projects due to their need for work.

The participation in PPP projects may help private investors have more opportunities to enhance relationship with lenders (financial institutions), with contractors, consultants, operators companies, as well as with construction industry [1]. Furthermore, based on research by Demirag et al. [5], reputation, and familiarity with industry and client relationships were the most common cited non-financial criteria for decisions to participate in a PFI project. The list of concern factors (Table 1) related to opportunities involves six key factors, including assessing/seeking new markets (OP1); enhancing relationship with lenders (OP2); enhancing relationship with contractors, project management, or operator companies (OP3); enhancing company's strength in its industry (OP4); value of image to other clients (OP5); and need for work (OP6).

\section{Category 4 -Risk of PPP Projects}

PPP transportation projects have a complex financial and organizational structure. The projects are also influenced by the socio-economic environmental of a host country. This leads to an assessment of the level of risk as an important step for investors before participating in this type of project. According to the viewpoints of private investors in research of $\mathrm{Ng}$ et al. [12], consideration the feasibility of PPP project's political and legal is essential prior to submitting a concession proposal. Indeed, the unstable political and social environment (frequent changes in the government cabinet) will lead to the failure of the rail projects in Bangkok. Therefore, private investors need to understand all the risks and have plans to cope with them accordingly. Their proposals must be adaptable to the changing circumstances and government demands. For example, private investors select the appropriate financial strategy for risk in the project, the conditions of the project, and finally, the availability of financial resources [10]. In summary, the concern factors related to risk of PPP projects are included in two main categories: general risks (political, legal, and commercial) and project-specific risks (design and procurement, construction, and operation) (see Table 1). 


\section{Research Methodology}

The research methodology consists of a questionnaire survey and in-depth interviews. A relevant literature review and current PPP practices were initially conducted to identify the concern factors that will affect the strategic investment of private investors in PPP transportation projects in Vietnam. Seven experienced professionals participated in the pilot test entailed two officers from the Ministry of Planning and Investment, a PPP investor, a consultant, a contractor, and two university lecturers were conducted to finalize the questionnaire.

The questionnaire survey was conducted in Vietnam in around three months from August to October, 2014. The objectives of the survey were to investigate the concern factors of private investors, risk factors affecting the performance of the private sector, the investment willingness attributes and criteria of the private sector, and the most common and effective responsive strategies that the private sector adopted for their investment willingness in PPP transportation projects in Vietnam. The questionnaire survey encompassed several issues regarding the investment in PPP transportation projects in Vietnam; nonetheless, this paper presents only the concern factors that affecting strategic investment of the private sector.

To elicit the important level of concern factors, the respondents were asked to indicate the important level of the concern factors according to the five-point Likert scale: 5 for very important, 4 for important, 3 for neutral, 2 for unimportant, and 1 for very unimportant.

Totally, 320 questionnaires were delivered directly (face-to-face) in Vietnam. Responses to the questionnaire were then collected and analyzed. In order to check internal consistency reliability of data, Cronbach's alpha coefficient values were conducted in this research. The obtained Alpha scores of company capability, finance, opportunities, and risk of PPP projects groups were calculated by SPSS 22 of $0.617,0.670,0.730$, and 0.610 , respectively. The results of reliability analysis have shown that all Cronbach's alpha values exceeded accepted reliability value of 0.60 [33], which is considered reliable.

The critical concern factors were analyzed based on their mean rankings. The analysis also examines whether or not perceptions of different groups (public and private) affect their rankings. The Spearman's rank correlation coefficient $\left(r_{s}\right)$ was used to test the level of agreement as perceived between the public and private sectors. Finally, an independent sample $t$ test was carried out to statistically examine the differences in the perceptions of the two respondents’ groups.

\section{Analysis}

The questionnaire was then finalized and distributed to the Vietnamese experienced professionals in a large-scale survey. Direct delivery or face-to-face interview was preferred to motivate respondents and to guarantee the accuracy of answers and improve feedback rate. The respondents were divided into two groups: 1) the public sector and 2) the private sector. The private sector included private investors, consultants, contractors, financiers and designers who are experienced in PPP schemes, while officers in relevant government department were targeted in the public sector. Altogether 320 questionnaires were administered in Vietnam, out of which, 123 valid responses were received representing a response rate of more than 38 percent. The distribution of respondents according to stakeholders is shown in Table 2.

More than half (57.7\%) of the respondents were line directors and project managers, followed by directors/deputy directors (23.6\%) and project managers (34.1\%). The proportions of the respondents in terms of number of experience years in construction were: $43.1 \%$ 
(between 5 and 10 years) and 56.9\% (10 year or more). More than $90 \%$ of respondents were mostly experienced in equal or more than one PPP transportation projects. This implies that the research can reflect the current situation of PPP transportation projects in Vietnam.

Table 2. Questionnaire Return Rate

\begin{tabular}{lllll|lc}
\hline Stakeholder & $\begin{array}{l}\text { Questionnaire } \\
\text { Distributed }\end{array}$ & $\begin{array}{l}\text { Response } \\
\text { Received }\end{array}$ & $\begin{array}{l}\text { Response } \\
\text { Rate }\end{array}$ & $\begin{array}{l}\text { Proportion } \\
\mathbf{( \% )}\end{array}$ & Partner & Number \\
\hline $\begin{array}{l}\text { Private } \\
\text { Investors }\end{array}$ & 132 & 55 & $41.7 \%$ & $44.7 \%$ & $\begin{array}{l}\text { Private } \\
\text { sector* }\end{array}$ & 98 \\
Government & 43 & 25 & $58.1 \%$ & $20.3 \%$ & $\begin{array}{l}\text { Public } \\
\text { sector }\end{array}$ & 25 \\
$\begin{array}{l}\text { Agencies } \\
\text { Consultants }\end{array}$ & 61 & & & & Total & $\mathbf{1 2 3}$ \\
Contractors & 53 & 27 & $44.3 \%$ & $22.0 \%$ & & \\
Financiers & 20 & 10 & $18.9 \%$ & $8.1 \%$ & & \\
$\begin{array}{l}\text { Designers } \\
\text { Total }\end{array}$ & 11 & 5 & $25.0 \%$ & $4.1 \%$ & & \\
\hline
\end{tabular}

*The private sector includes private investors, consultants, contractors, financiers and designers

The rankings of 22 concern factors are shown in Table 3. The ranking in different categories are presented in Table 4, Table 5, Table 6, Table 7, and Table 8 for concern groups, company profile, finance, opportunities, and risks, respectively. The criticality of the 22 concern factors ranges from the lowest value of 3.31 (need for work - OP6) to the highest value of 4.47 (financial viability of the company - CP2). Interestingly, all of respondents evaluated all concern factors that have a mean above the average important level of 3 . The results of onesample $t$-test (test value $=3$; significant level $=95 \%$ ) indicated that all 22 concern factors had significantly high criticalities. Capacity of company (i.e.,financial viability and management capacity), finance issues (i.e.,return on equity, profitability, and finance sources) and risk issues (i.e., legal, political, commercial, and design and procurement risks) were the most critical concern factors; they received a mean score of equal or higher than 3.90. Operation risks and need for work were two least critical concern factors, with means of 3.33 and 3.31, respectively.

\section{Analysis on Group Basis}

\section{Analysis on Critical Concern Factors of the Private Sector}

To deeply investigate the effect of critical concern factors of the private sector on the investment willingness into PPP transportation projects in Vietnam, mean score techniques were used to rank all the concern factors. According to the opinions of experienced professionals and important level from 1 (very unimportant) to 5 (very important), the critical concern factors are the factors that have mean scores equal or higher than 3.5 ( $>3$ - neutral important). As a result, there are 19 critical concern factors (CCFs) as shown inTable 3. Among thesecritical concern factors, five most critical concern factors were identified including financial viability of the company (CP2), management capacity of the company (CP1), demand issues (FP6), legal risks (RP2), and possibility of long-term income (FP2). 
In order to carefully investigate which sectors and concern categories were involved for these concern factors, concern categories were then ranked in terms of perceptions of public, private and overall as shown inTable 4. Regarding important level of concern factors, both the public and private sectors agreed about the ranking of all concern factors categories. "Finance", "company capability", and "risks" of PPP projects issues were the most concern category issues of private investors when they would like to promote investment in Vietnam, whereas "opportunities" of PPP projects were the least critical concern group (still critical due to its mean $\geq 3.5$ ). Therefore, the critical concern factors in each category should be investigated carefully in the following.

\section{Concern Group 1: Company Capacity}

Concern factors related to capacity of partners who joined into concession company have to be scrutinized in PPP transportation projects. Private investors tend to be linked together to improve the capacity of their company (e.g. finance, management, resources, and experience). The results of this study showed that the finance and management abilities were evaluated key concerns of private investors as they plan to invest in PPP transportation projects in Vietnam (see Table 5).

Table 3. Concern Factors of PPP Transportation Projects in Vietnam

CODE CONCERN FACTOR OVERALL PUBLIC PRIVATE

\begin{tabular}{|c|c|c|c|c|c|c|c|c|c|c|}
\hline \multirow{2}{*}{\multicolumn{2}{|c|}{ I. COMPANY CAPABILITY }} & Mean & \multirow[t]{2}{*}{ SD } & \multirow[t]{2}{*}{ Rank } & \multirow[t]{2}{*}{ Mean } & \multirow[t]{2}{*}{ SD } & \multirow[t]{2}{*}{ Rank } & \multirow[t]{2}{*}{ Mean } & \multirow[t]{2}{*}{ SD } & \multirow[t]{2}{*}{ Rank } \\
\hline & & & & & & & & & & \\
\hline $\mathrm{CP} 1$ & $\begin{array}{l}\text { Management capacity of } \\
\text { the company }\end{array}$ & 4.31 & 0.62 & 2 & 4.16 & 0.62 & 6 & 4.33 & 0.62 & 2 \\
\hline CP2 & $\begin{array}{l}\text { Financial viability of the } \\
\text { company }\end{array}$ & 4.47 & 0.56 & 1 & 4.80 & 0.41 & 1 & 4.37 & 0.57 & 1 \\
\hline CP3 & $\begin{array}{l}\text { The company's resources } \\
\text { about labor, machinery, } \\
\text { engineering }\end{array}$ & 3.60 & 0.67 & 15 & 3.56 & 0.82 & 16 & 3.64 & 0.64 & 16 \\
\hline CP4 & $\begin{array}{l}\text { The company's experience } \\
\text { with same project before }\end{array}$ & 3.76 & 0.69 & 12 & 3.68 & 0.63 & 12 & 3.76 & 0.71 & 12 \\
\hline \multicolumn{11}{|c|}{ II. FINANCE OF PPP PROJECTS } \\
\hline FP1 & $\begin{array}{l}\text { Return on equity } \\
\text { investment }\end{array}$ & 4.17 & 0.70 & 7 & 4.08 & 0.64 & 8 & 4.18 & 0.72 & 3 \\
\hline FP2 & $\begin{array}{l}\text { Possibility of long-term } \\
\text { income }\end{array}$ & 4.22 & 0.77 & 5 & 4.40 & 0.65 & 3 & 4.15 & 0.82 & 6 \\
\hline FP3 & Project cash flows & 4.15 & 0.69 & 8 & 4.16 & 0.69 & 7 & 4.16 & 0.71 & 5 \\
\hline BP4 & $\begin{array}{l}\text { Availability of financing } \\
\text { sources }\end{array}$ & 4.20 & 0.73 & 6 & 4.36 & 0.57 & 4 & 4.10 & 0.77 & 9 \\
\hline FP5 & Tax/tariff issues & 3.67 & 0.75 & 13 & 3.56 & 0.77 & 15 & 3.69 & 0.78 & 14 \\
\hline FP6 & Demand issues & 4.24 & 0.68 & 3 & 4.52 & 0.59 & 2 & 4.12 & 0.69 & 7 \\
\hline \multicolumn{11}{|c|}{ III. OPPORTUNITIES OF PPP PROJECTS } \\
\hline OP1 & $\begin{array}{l}\text { Assess/seek to new } \\
\text { markets }\end{array}$ & 3.56 & 0.80 & 17 & 3.76 & 0.83 & 11 & 3.54 & 0.8 & 18 \\
\hline OP2 & $\begin{array}{l}\text { Enhancing relationship } \\
\text { with lenders }\end{array}$ & 3.51 & 0.72 & 19 & 3.60 & 0.65 & 13 & 3.51 & 0.76 & 19 \\
\hline
\end{tabular}




\begin{tabular}{|c|c|c|c|c|c|c|c|c|c|c|}
\hline \multirow[t]{2}{*}{ CODE } & \multirow[t]{2}{*}{ CONCERN FACTOR } & \multicolumn{3}{|c|}{ OVERALL } & \multicolumn{3}{|c|}{ PUBLIC } & \multicolumn{3}{|c|}{ PRIVATE } \\
\hline & & Mean & SD & Rank & Mean & SD & Rank & Mean & SD & Rank \\
\hline OP3 & $\begin{array}{l}\text { Enhancing relationship } \\
\text { with contractors, project } \\
\text { management, or operator } \\
\text { companies }\end{array}$ & 3.43 & 0.79 & 20 & 3.48 & 0.77 & 17 & 3.42 & 0.82 & 20 \\
\hline OP4 & $\begin{array}{l}\text { Enhancement } \\
\text { company's strength in its } \\
\text { industry }\end{array}$ & 3.63 & 0.78 & 14 & 3.24 & 0.88 & 21 & 3.71 & 0.74 & 13 \\
\hline OP5 & $\begin{array}{l}\text { Value of image to other } \\
\text { clients }\end{array}$ & 3.53 & 0.74 & 18 & 3.36 & 0.91 & 18 & 3.54 & 0.71 & 17 \\
\hline OP6 & Need for work & 3.31 & 0.84 & 22 & 3.12 & 0.83 & 22 & 3.42 & 0.85 & 21 \\
\hline \multicolumn{11}{|c|}{ IV. RISK OF PPP PROJECTS } \\
\hline RP1 & Political risks & 3.97 & 0.80 & 9 & 3.32 & 1.11 & 20 & 4.11 & 0.59 & 8 \\
\hline RP2 & Legal risks & 4.23 & 0.76 & 4 & 4.36 & 0.76 & 5 & 4.18 & 0.76 & 4 \\
\hline RP3 & Commercial risks & 3.90 & 0.59 & 10 & 3.96 & 0.45 & 9 & 3.88 & 0.62 & 10 \\
\hline RP4 & $\begin{array}{l}\text { Design and procurement } \\
\text { risks }\end{array}$ & 3.90 & 0.75 & 11 & 3.96 & 0.68 & 10 & 3.87 & 0.79 & 11 \\
\hline RP5 & Construc & 3.59 & 0.76 & 16 & 3.32 & 0.63 & 19 & 3.65 & 0.8 & 15 \\
\hline RP6 & Operation risks & 3.33 & 0.7 & 21 & 3.56 & 0.58 & 14 & 3.24 & 0.71 & 22 \\
\hline
\end{tabular}

Table 4. Ranking of Important Level of Concern Factor Categories

\begin{tabular}{lcccccc}
\hline \multirow{2}{*}{ CATEGORIES } & \multicolumn{3}{c}{ OVERALL } & \multicolumn{5}{c}{ PUBLIC SECTOR PRIVATE SECTOR } \\
\cline { 2 - 7 } & Mean & Rank & Mean & Rank & Mean & Rank \\
\hline Company capability & 4.04 & 2 & 4.05 & 2 & 4.03 & 2 \\
Finance of PPP projects & 4.11 & 1 & 4.18 & 1 & 4.07 & 1 \\
Opportunities of PPP projects & 3.50 & 4 & 3.43 & 4 & 3.52 & 4 \\
Risks of PPP projects & 3.82 & 3 & 3.75 & 3 & 3.82 & 3 \\
\hline
\end{tabular}

Investors' finance capacity: Among the four factors in Table 5, the most critical factor is financial viability of the company (CP2). It received a mean of $4.47\left(1^{\text {st }}\right.$ ranking), which means that financial viability of their own company was considered the most important concern factors of PPP transportation projects in Vietnam. Thus, private investors have to prepare adequate financial as well as specific plans to address financial problems before deciding to participate in PPP transportation projects.

Investors' management capacity: Another critical concern factor of private investors is management capacity of the company (CP1). It received the $2^{\text {nd }}$ ranking. Management capabilities of private investors are related to issues such as organizational management and work collaboration. The PPP projects are regularly very large and complex, and a lot of stakeholders (i.e., the public sector, investors, lenders, contractors, subcontractors, and especially users/customers) are associated with the projects. Finance, resources, operation issues are also related to the projects. Thus, private investors must prepare themselves with a good management skills to cope with these issues.

Experience with the similar project before (CP4) and resources of the company (CP3) were considered the least concern factors in this group. 


\section{Concern Group 2: Finance of PPP Projects}

Concern factors related to finance situation of PPP projects also have to be scrutinized in PPP transportation projects. Private investors tend to be linked together to implement these projects in order to reduce the financial risk. Therefore, the finance characteristics of PPP projects could influence significantly on the investment willingness of the private sector. Indeed, research results showed that more than $80 \%$ (5 out of 6 ) concern factors were evaluated strategic concerns of private investors when they plan to invest into PPP transportation projects (see Table 6).

Demand issues: Among the six concern factors in 'finance of PPP projects" group, the most critical concern factors is the demand issues (FP6), it received the $1^{\text {st }}$ ranking. Indeed, it is entirely consistent with the actual situation in Vietnam. For example, the failures of Yen Lenh Bridge [34], Ong Thin Bridge and Phu My Bridge resulted from the underestimated demand analysis of these project.

Table 5. Group 1: Company Capacity

\begin{tabular}{cclcc}
\hline Rank & Code & Concern Factor & Mean & SD \\
\hline 1 & CP2 & Financial viability of the company & 4.47 & 0.56 \\
2 & CP1 & Management capacity of the company & 4.31 & 0.62 \\
3 & CP4 & The company's experience with same project before & 3.76 & 0.69 \\
4 & CP3 & The company's resources about labor, machinery, engineering & 3.60 & 0.67 \\
\hline
\end{tabular}

Cronbach's Alpha $=0.617$

Table 6. Group 2: Finance of PPP Projects

\begin{tabular}{cclcc}
\hline Rank & Code & \multicolumn{1}{c}{ Concern Factor } & Mean & SD \\
\hline 1 & FP6 & Demand issues & 4.24 & 0.68 \\
2 & FP2 & Possibility of long-term income & 4.22 & 0.77 \\
3 & FP4 & Availability of financing sources & 4.20 & 0.73 \\
4 & FP1 & Return on equity investment & 4.17 & 0.70 \\
5 & FP3 & Project cash flows & 4.15 & 0.69 \\
6 & FP5 & Tax/tariff issues & 3.67 & 0.75 \\
\hline
\end{tabular}

Cronbach's Alpha $=0.670$

Project's profitability: Possibility of long-term income (BP2) is also a critical concern factor of private investor. It received a $2^{\text {nd }}$ ranking. Another concern factor related to a profitability of projects is return on equity investment (BP1), which is ranked $4^{\text {th }}$. These factors were clearly related to the profitability during the life cycle of PPP projects. Indeed, profitability was mentioned by most of respondents in this research is one of the most concern issue of private investors due to the influence directly into decision making process to participate in PPP projects.

Availability of financing sources: Another critical concern factor is an availability of financing sources (BP4). It received a critical value of 4.20 and so was ranked 3rd in the finance of PPP projects group. Thus, a lack of availability of financing sources (e.g., the investors cannot find the lenders, financing institutions or other cooperation investors) of private investors could lead to quit or give up investing to PPP transportation projects. 
Project's cash flow: A project cash flow (BP3) issue is regarded as the most critical concern factor to PPP projects. Although it ranked $5^{\text {th }}$, it received a very high value of important level (value $=4.15$ ). Indeed, some problems of public's cash flow might cause barriers to entry by private investors. Therefore, the cash flow of PPP projects is the most concern issues of private investors in the process of investment decision making.

\section{Concern Group 3: Opportunities of PPP Projects}

The rankings of six concern factors of this group are shown in Table 7. The criticality of the six concern factors ranges from the lowest value of 3.31 (need for work - OP6) to the highest value of 3.63 (Enhancement of company's strength in its industry - OP4). Obviously, all of respondents evaluated that all concern factors in this group that have mean scores higher than the average important level (value $=3$ ). The importance of getting more opportunities in PPP project was not highly appreciated in Vietnam. This proved that the investment environment of Vietnam is still not attractive enough for private investors (i.e., domestic and international companies) to enhance their new opportunities.

Enhancement their capacities: Among the six concern factors in 'opportunities of PPP projects” group, the most critical concern factor is enhancement of company's strength in its industry (OP4). The mean of this factor is 3.63. Other concern factors related to enhancement the relationships are enhancing relationship with lenders (OP2- $\left.4^{\text {th }}\right)$ and enhancing relationship with contractors, project management, or operator companies $\left(\mathrm{OP} 1-5^{\text {th }}\right)$. Thus, investing to PPP transportation projects would help private companies to improve or create good relationships with other private investors, contractors, consultants and operators in the host country. This results accords with the research by Kwak et al. [1].

Seeking new markets:Assess or seek to new markets (OP1) is critical and this concern factor was ranked $2^{\text {nd }}$ in this group. It can be said that opportunities to entry new markets can affect private investors' decisions while they may have a lower profit contribution [6].

Reputation: Value of image to other investors (OP5) also plays a significant role, and this concern factors was ranked $3^{\text {rd }}$. There are plenty of opportunities for private investors to enhance their reputation or capacity profile when promoting in PPP transportation projects. This means that private companies might get the strong reputation for the similar projects in the future.

Need for work.Need for work (OP6) is the least critical factor in this group. This strategy might be helpful for small or medium companies (e.g. subcontractors, suppliers, and operators participate in the project) to get works during the period of employment crisis.

\section{Concern Group 4: Risks of PPP Projects}

Concern factors related to "risks of PPP projects" consist of two main groups, such as general risks and project-specific risks. The general risks contain the legal, political, and commercial risks factors whereas the project-specific risks include design and procurement, construction, and operation risk factors (see Table 8).

Table 7. Group 3: Opportunities of PPP Projects

\begin{tabular}{cclcc}
\hline Rank & Code & Concern Factor & Mean & SD \\
\hline 1 & OP4 & Enhancement of company's strength in its industry & 3.63 & 0.78 \\
2 & OP1 & Assess/seek to new markets & 3.56 & 0.80 \\
3 & OP5 & Value of image to other clients & 3.53 & 0.74
\end{tabular}




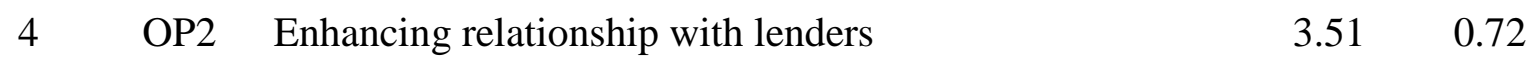

OP3 Enhancing relationship with contractors, project

5 management, or operator companies $\quad 3.43 \quad 0.79$

$\begin{array}{lllll}6 & \text { OP6 Need for work } & 3.31 & 0.84\end{array}$

Cronbach's Alpha $=0.730$

Table 8. Group 4: Risk of PPP Projects

\begin{tabular}{cclcc}
\hline Rank & Code & Concern Factor & Mean & SD \\
\hline 1 & RP2 & Legal risks & 4.23 & 0.76 \\
2 & RP1 & Political risks & 3.97 & 0.80 \\
3 & RP3 & Commercial risks & 3.90 & 0.59 \\
3 & RP4 & Design and procurement risks & 3.90 & 0.75 \\
5 & RP5 & Construction risks & 3.59 & 0.76 \\
6 & RP6 & Operation risks & 3.33 & 0.70 \\
\hline
\end{tabular}

Cronbach's Alpha $=0.610$

Legal risks: Legal risks include inadequate law and supervision system; change in laws and regulations; and tariff change. Among the six risk groups in Table 8 , the most critical concern factor is the legal risks. It received a mean of 4.23, far higher than the remaining factors. In some developing countries like Vietnam, the legal systems are very complicated, the laws and regulations overlap, and some of them contradict with each other [2,35]. Therefore, it can be said that the stability of legal framework might have great influence on attracting private investors to engage in PPP transportation projects since PPP is still a very new form in Vetnam.

Political risks: Political risks factor comprises of many sub-factors such as government's intervention; approvals and permits issues; and corruption, etc. Political risks factor is also the most critical factor, and this concern factor was ranked $2^{\text {nd }}$. In Vietnam, government directly influences the public construction sector by setting the rules for development and contractual relationships. Moreover, their influence is also identified in the private sector through policies and legislation regarding approvals and permits, taxes, availability of financing for construction, and corruption. Therefore, Vietnamese government should concentrate on improving the political environment in order to attract private investors so that they are going to ready to invest in infrastructure projects, particularly in PPP transportation projects.

Commercial risks: Commercial risks factor includes some sub-factors such as financial market issues, fluctuation of interest rate, foreign exchange rate, and instability of inflation. The results of this study showed that the commercial risks factor is also critical concern for private investors. This factor was ranked $3^{\text {rd }}$, and its mean was 3.90 . It can be said that the evaluation of financial viability is the most commonly used for assessing the potential of project to achieve the financial targets of private investors [36]. Moreover, interest rate, foreign exchange rate or inflation are impossible to manage or predict. Instability of interest rate and inflation would cause the undesirable financial condition of all sectors in the projects in terms of potential profit.

Design and procurement risks: Design and procurement risks factor consists of some sub-factors related to procurement and design phases of PPP projects, including lack of transparency in the bidding, supporting incentive of government risk, unclear about state participant portion, inefficient feasibility study, unfair process of selection of the private 
sector, and low capacity of concession company. This factor is very important and it was ranked $4^{\text {th }}$. The procurement and design phases are so complicated and private investors must spend plenty of time during these phases on PPP transportation projects. It is very important to determine the success or failure of projects throughout selection process of investors, investment forms, total investment, and concession period.

Construction and operation risks: Compared with the other concern factors, construction risks and operation risks were considered to be less critical, and they were ranked last in this group, but it is still quite critical concern for private investors because their mean score were 3.59 and 3.33, respectively.

\section{Different Concern Perceptions between the Public and Private Sectors}

Empirical analysis was then conducted to test the consensus amongst two groups of respondents on their ranking using the Spearman's rank correlation test. These relations between rankings of two groups are verified by hypothesis testing at the $1 \%$ significant level. The Spearman's correlation coefficients for ranking of important levels of the concern factors between the public and private sectors is 0.740. Table 9 summaries the Spearman's rank correlation coefficients and corresponding significant levels. It suggests that the null hypotheses that no significant correlation between the public and private sectors can be rejected. It implies a high degree of agreement (i.e., $r_{s}$ from 0.5 to 1.0) between two groups on the level of important of concern factors [37].

Although the results of the Spearman's correlation test exposed that the public and private respondents shared a fairly consistent view on the ranking of concern factors of the private sector in PPP transportation projects in Vietnam, the analysis of ranking of concern factors designates some interesting results. As illustrated inTable 3, there are 19 critical concern factors (CCFs) based on the perception of the private sector's respondents whereas only 16 CCFs were recognized by the public sector's respondents. The public sector ranked "demand issues" (BP6) and “operation risks" (RP6) as the $2^{\text {nd }}$ and $14^{\text {th }}$, whereas the private sector ranked them the $7^{\text {th }}$ and $22^{\text {nd }}$, respectively. Similar results were also found in "assess/seek to new markets" (OP1), and "enhancing relationship with lenders” (OP2). The ranking exercise further unveiled the different interest of the public sector from the private sector, particularly on the ranking of "enhancement of company's strength in its industry” (OP4), "management capacity of the company" (CP1) and "construction risks" (RP5). Therefore, in order to clarify the difference perceptions of two groups about concern factors of the private sector in Vietnam, the public and private sectors' perceptions were compared through independent sample t-testmethodto confirm any significant difference (at $\alpha=5 \%$ ). The null hypothesis was that there was no significant difference between the public and private sectors' perceptions. Finally, cross-comparison by spider diagram among the public and private sectors are shown in Figure 2 and concern factors with significant differences between public and private under t-test are displayed in Table 10. 
Table 9. Spearman's Rank Correlation Coefficient Test between Groups for Concern Factors of Private Investors in PPP Projects

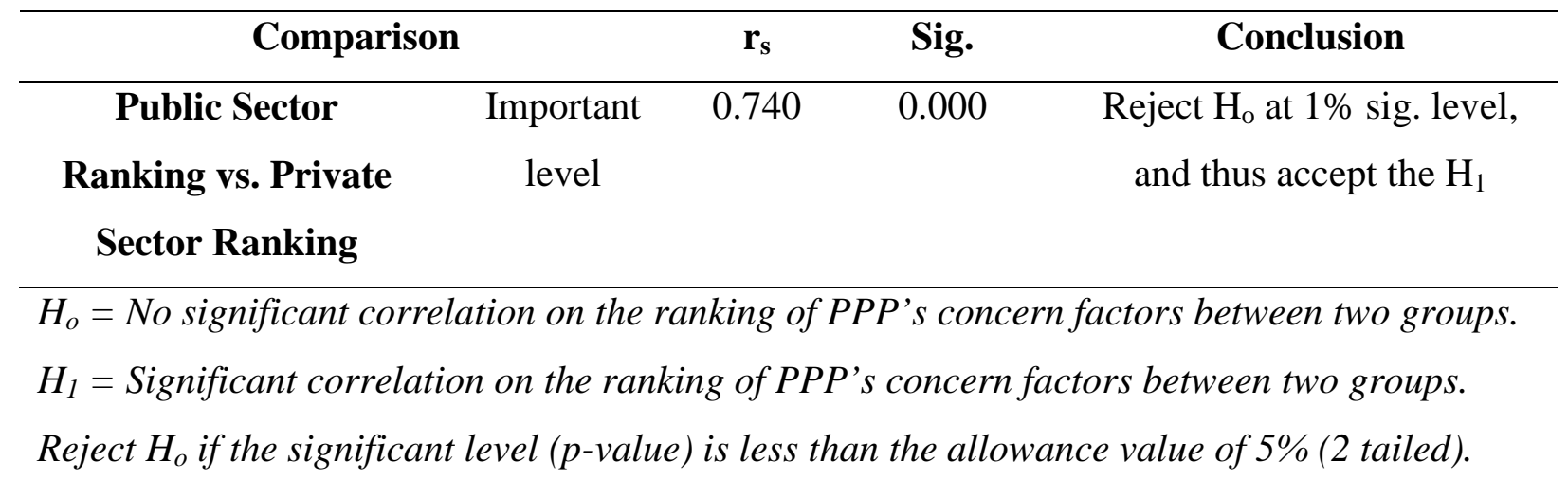

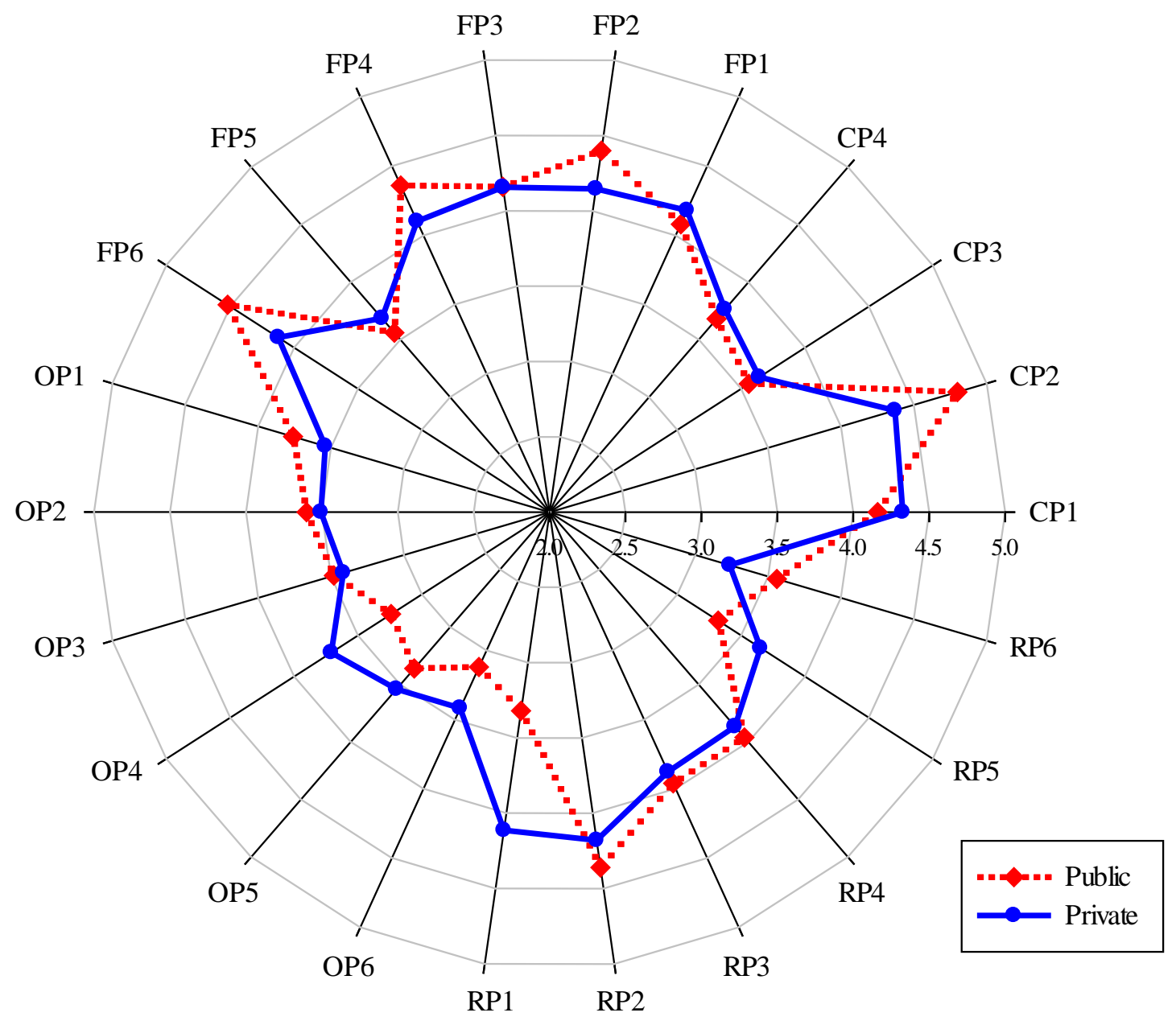

Figure 2. Cross-comparison by spider diagram among the public and private sectors 
Table 10. Factors with Significant Difference between Public Vs Private under T-Test

\begin{tabular}{|c|c|c|c|c|c|c|c|c|}
\hline & $\begin{array}{r}\text { Levene's Test } \\
\text { of Vari }\end{array}$ & $\begin{array}{l}\text { for Equa } \\
\text { ances }\end{array}$ & & t-tes & $\begin{array}{r}\text { for Eq } \\
\text { Mea }\end{array}$ & $\begin{array}{l}\text { lality of } \\
\text { ns }\end{array}$ & & \\
\hline CFs & Assumption & $\mathbf{F}$ & Sig. & $\mathbf{t}$ & df & $\begin{array}{c}\text { Sig } \\
\text { (2tailed) }\end{array}$ & $\begin{array}{l}\text { Mean } \\
\text { Diff. }\end{array}$ & $\begin{array}{l}\text { Std. } \\
\text { Error } \\
\text { Diff. }\end{array}$ \\
\hline \multicolumn{9}{|c|}{ Private Sector vs. The Public Sector } \\
\hline Political risks (RP1) & $\begin{array}{l}\text { Equal } \\
\text { variances not } \\
\text { assumed }\end{array}$ & 26.580 & .000 & 3.537 & 27.728 & .001 & 0.813 & 0.230 \\
\hline $\begin{array}{l}\text { Enhancement of } \\
\text { company's strength } \\
\text { in its industry (OP4) }\end{array}$ & $\begin{array}{l}\text { Equal } \\
\text { variances } \\
\text { assumed }\end{array}$ & 1.568 & .213 & 2.840 & 121 & .005 & 0.484 & 0.171 \\
\hline $\begin{array}{l}\text { Construction risks } \\
\text { (RP5) }\end{array}$ & $\begin{array}{l}\text { Equal } \\
\text { variances not } \\
\text { assumed }\end{array}$ & 4.151 & .044 & 2.324 & 44.524 & .025 & 0.343 & 0.148 \\
\hline $\begin{array}{l}\text { Financial viability of } \\
\text { the company (CP2) }\end{array}$ & $\begin{array}{l}\text { Equal } \\
\text { variances } \\
\text { assumed }\end{array}$ & 17.680 & .000 & - & 50.482 & .000 & -0.412 & 0.100 \\
\hline
\end{tabular}

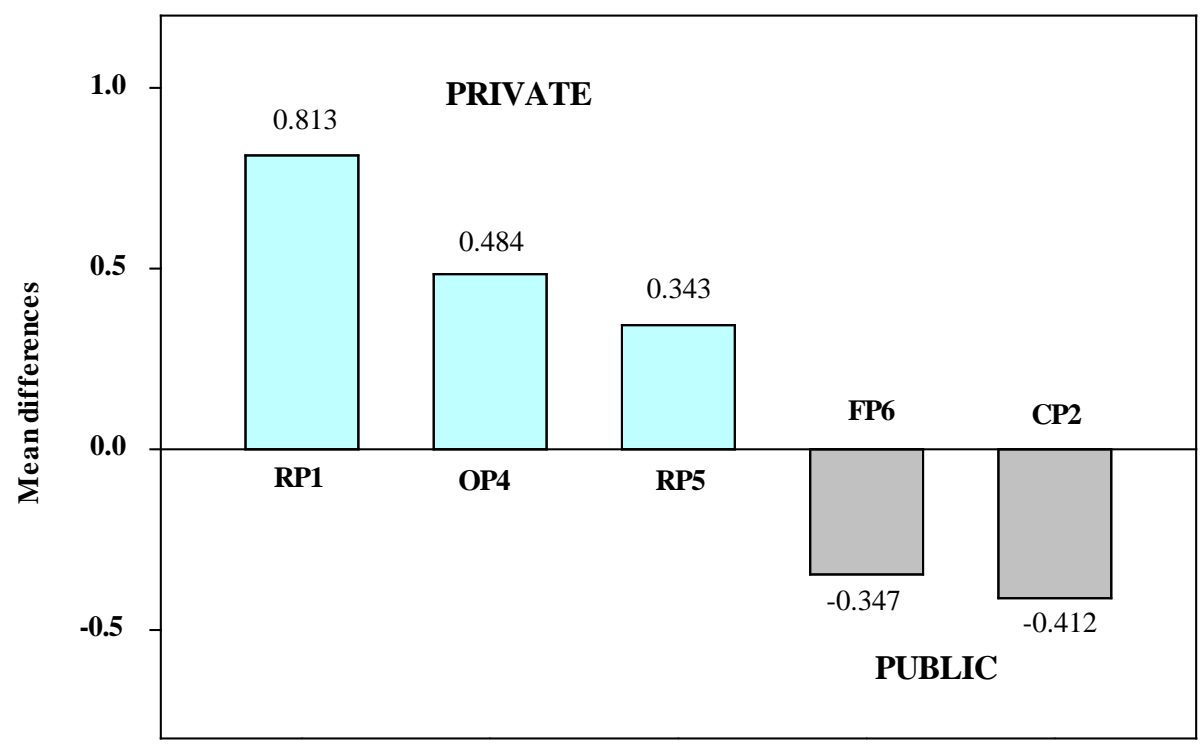

Figure 3. Mean differences between the private and public sectors’ perceptions

Firstly, there is no significant difference in the perceptions of the public and private organizations as to concern factors of private investors in PPP on company capacity (i.e., management skill, resources, and experiences), projects' benefits (i.e., ROE, long-term income, cash flows, financing sources, and tariff issues); new markets entrance, enhancing relationship with stakeholders, reputation; and projects' risks (i.e., legal, commercial, design and procurement, operation risks). Thus, the public sector can realize some expectations for investment strategic of the private sector. 
Interestingly, the study findings reveal that around one-fourth of concern factors (5 out of 22) shows a significant difference in the perception of public and private organizations about concern factors of the private sector when they intend to invest in PPP transportation projects. Five concern factors with significant difference among the public and private sectors(Table 10) are financial viability of the company (CP2), demand issues (BP6), enhancement of company's strength in its industry (OP4), political risks (RP1), and construction risks (RP6). Factors with great mean difference between the private and public sectors are "political risks" (mean difference - MD $=0.813$ ), "enhancement of company's strength in its industry" (MD =0.484), and "construction risks" (MD =0.343). Otherwise, factors with great difference between the public and private sectors are "financial viability of the company” ( $\mathrm{MD}=0.412$ ) and “demand issues" ( $\mathrm{MD}=0.347$ ) (see Figure 3). These differences can be recognized to the fact that the public and private sectors have different points of views and perspectives. For instance, the private sector are more concerned about the political situation, capacity improvement of their companies, and risks in construction phase, whereas the public notion that the private sector more concerned about financial viability of the company as well as the market demand of PPP transportation projects. The details of such concern factors are uncovered as follows.

\section{Political Issues (RP1)}

PPP transportation projects regularly have complex financial and organization structures. In addition, these projects are also influenced by the socio-economic environmental, especially political situation of a host country. Indeed, regarding previous research works, the major risk which is considered potential to PPP projects is a lack of political support $[10,12]$. The unstable politics may lead to many changes in policies, resulting in the cancellation of several new PPP projects. For instance, within frequent change in government premiers in Bangkok, Thailand, it led to the termination of many new PPP public infrastructure projects [22]. In Vietnam, government induced directly influences on PPP transportation projects through setting the rules for development and contractual relationships. Moreover, their influences were also indicated in the private sector through policies and legislation regarding approvals and permits, taxes, availability of financing for construction, and corruption. The stability of political climate was a good condition to attract private investors during the pre-feasibility phase of PPP projects [14]. Therefore, Vietnamese government needs to stabilize the political environment (e.g. improve investment environment, restrict corruption, and improve approvals/permits process) to be able to call investment capital from the private sector, especially international investors.

\section{Enhancement of Company's Strength in its Industry (OP4)}

Private investors moreover would like to improve their reputation and familiarity relationships in its industry when they decide to invest in PPP transportation projects in Vietnam. This result accords with the previous research by Demirag et al. [5] about non-financial criteria for decisions to participate in a PFI projects. Moreover, a fair and transparent investment environment is considered the biggest concern of private investors, especially international investors. Thus, private investors must enhance their capacities in the industry to increase probability to win competitive tendering process when considering to participate in PPP projects. Consequently, in order to attract more participation of private investors,public sector from central to local level have to establish adequate legal framework for PPP form, and transparent and professional procurement system. 


\section{Construction Risks (RP5)}

It also has a significant difference in perception between the private and public sectors about construction risks in PPP projects. Private investors concerned about the risks incurred during the life-cycle of PPP transportation projects. Particularly, they are interested in the quality of domestic contractors, subcontractors, and suppliers related to these processes. The quality of projects' stakeholders affects greatly to the time, cost, quality and scope of the project. Moreover, in investors' perception, the role of state management during the construction process is very important, which determine the success or failure of PPP transportation projects.

\section{Financial Viability (CP2)}

The financial capacity of private investors is one of the critical concern issues of the private sector. Indeed, searching and cooperating with potential investors is one inevitable factor which will bring success for PPP projects. Moreover, private investors need to pay attention to disputes among equity partners as well as adverse changes in the parent organizations of equity partners which will have large effect to financial viability of concession companies. Especially, private investors do often expect a lot of supporting or incentive policies from the public sector, whereas the government highly appreciate the role of the private sector in the success or failure of projects. For instance, financial viability was effected by a lot of sudden changes in cost of debt [19], such as interest changes by government, fluctuation of foreign exchange, liquidity, and fluctuation of capital markets. Thus, guarantees, assurances, and incentive policies by the government (i.e., loan guarantees) would improve the viability of PPP transportation projects in "call for investment" stage [21]. Consequently, the ability of private investors and the supporting incentives from government should achieve the balance to ensure the investment from the private sector.

\section{Demand Issues (FP6)}

Demand issues is one of the most critical concern factor had a significant difference in perception between private and public sectors. It received the $2^{\text {nd }}$ and $7^{\text {th }}$ ranking in perceptions of the public and private sectors, respectively. Certainly, demand forecasts of project was a determinant factor affecting investors' decision to get involved [20]. However, assessing the exact demand of the project in Vietnam faced many difficulties. For instance, a lot of PPP projects in Vietnam, such as Yen Lenh Bridge [34], Ong Thin Bridge and Phu My Bridge, failed to meet expected revenues because the demand analysis was underestimated. Typically, fluctuations in project-related policies, changes in contractual commitments of government have affected the actual traffic revenues in Phu My Bridge projects. It can be said that private investors are concerned about the supporting policies from government to share the financial risk related to the demand issues more than demand issues itself [21].

\section{Conclusions}

The PPP form has been proclaimed as bringing a new age to infrastructure development in Vietnam. New consistent PPP regulations in 2015 and some pilot PPP projects were expected to open up many opportunities for foreign and domestic private investors to penetrate into new markets in Vietnam. However, attracting the participation of private investors in Vietnam are currently facing many difficulties due to the instability of the legal framework, investment 
environment, financial market, as well as the investment unwillingness of the private investors. The main objectives of this research are to unveil the critical concern factors and uncover the significant different perceptions between public and private about the private sector' concerns in PPP transportation projects in Vietnam. The results indicated that (1) the critical concern factors in such group basis; (2) the concern factors with significant different between the public and private sectors; and (3) some recommendations for government and lessons for private investors.

In order to invest in PPP transportation projects, the main concern or expectation factors of private investors are benefits or profits, their own capacity, and risks of projects. Opportunities when investing in PPP does not get critical expectations from respondents in this research. Among all of concern factors, those associated with capacity (i.e., finance, management) of private companies; profitability, demand of PPP projects; and legal, political, commercial risks are considered the most critical important for strategic investment of private investors.

Moreover, the concern factors that have significant difference among public and private in PPP transportation projects have been also identified and discussed. There are five significant difference concern factors, namely political risks, enhancement of company's strength in its industry, construction risks, demand issues, and financial viability of the company. The findings from these results would be helpful for Vietnamese government to understand the concerns as well as expectations of private investors in investment decision making process.

From these results, several recommendations for the public sector to attract the participation of the private sector into PPP transportation projects in Vietnam are as follows:

- Improve the political environment in Vietnam, such as limiting change of macroeconomic policies which affect long concession periods of PPP transportation projects.

- Establish adequate legal framework for PPP form

- Select qualified stakeholders through a fair bidding process.

- Establish transparent and professional procurement system.

- Improve the feasibility of PPP transportation projects by the guarantees, assurances, and incentive policies for private investors during early stage.

- Stabilize economic environment through appropriate monetary policies and enhance the attractiveness of PPP project through improving inner financial market.

- Implement the commitments to ensure demand for PPP transportation projects. Lessons for private investors

- Share knowledge with the public sector to create PPP-related policies and a favorable investment environment

- Get early involvement with the financial institutions

- Maintain long-term relationships with industrial partners

- Establish the concession company similar to a corporation which including many multidisciplinary companies.

\section{Acknowledgment}

The authors would like to thank the ASEAN University Network/Southeast Asia Engineering Education Development Network (AUN/SEED-net JICA), Chulalongkorn University, Kyoto University and Ho Chi Minh City University of Technology for their financial support to this paper. 


\section{References}

$>@$ @.H. Kwak, Y.Y. Chih, and C.W. Ibbs, “Towards a comprehensive understanding of 3ublic 3rivate 3artnerships for infrastructure development," California

Management Review, Vol. 51, No. 2, pp. 51-78, 2009.

$\gg @$ @.T. Sy, and V. Likhitruangsilp, "Public-private partnership transportation projects in Vietnam: Opportunities and challenges,” In The Twenty-Sixth KKCNN Symposium on Civil Engineering, Symposium conducted in University Town, Singapore, November 2013.

$\ngtr @$ @D.T. Sy, P.T. Nguyen, V. Likhitruangsilp, and M. Onishi , "Public-private partnership Infrastructure projects in Vietnam: Past, Sresent, and Iuture,” In The Twenty-Eighth KKHTCNN Symposium on Civil Engineering, Symposium conducted at Chulalongkorn University, Bangkok, Thailand, November 2015.

[4] F. Sader, Attracting Foreign Direct Investment Into Infrastructure: Why is it So Difficult?, East Asia - World Bank Publications, Washington D.C., 1999.

[5] I. Demirag, I. Khadaroo, P. Stapleton, and C. Stevenson, "Risks and the financing of PPP: Perspectives from the financiers,” The British Accounting Review, Vol. 43, No. 4, pp. 294-310, 2011.

[6] I.D. Ozdoganm, and M.T. Birgonul, “A decision support framework for project sponsors in the planning stage of build-operate-transfer (BOT) projects," Construction Management and Economics, Vol. 18, No. 3, pp. 343-353, 2000.

[7] A.M. Alquier, E. Cagno, F. Caron, V. Leopoulos, and M.A. Ridao, "Analysis of external and internal risks in project early phase," in The Frontiers of Project Management Research, D.P. Slevin, D. Cleland, and J. Pinto, eds.: Project Management Institute, Pennsylvania, United States, pp. 349-364, 2002.

[8] T.H.Y. Li, S.T. Ng, and M. Skitmore, "Evaluating stakeholder satisfaction during public participation in major infrastructure and construction projects: A fuzzy approach,” Automation in Construction, Vol. 29, pp. 123-135, 2013.

[9] D. Grimsey, and M.K. Lewis, "Evaluating the risks of public private partnerships for infrastructure projects," International Journal of Project Management, Vol. 20, No. 2, pp.107-118, 2002.

[10] J.E. Schaufelberger, and I. Wipadapisut, "Alternate financing strategies for buildoperate-transfer projects," Journal of Construction Engineering and Management, Vol. 129, No. 2, pp.205-213, 2003.

Ұ1@V. Cuttaree, Key Success Factors for PPP Projects Based on International Experience, World Bank, Europe \& Central Asia Region, St. Petersburg, 2008.

$\gg$ @ @.T. Ng, Y.M.W. Wong, and J.M.W. Wong, "A structural equation model of feasibility evaluation and project success for public-private partnerships in Hong Kong,” IEEE Transactions on Engineering Management, Vol. 57, pp. 310-322, 2010.

[13] R.L.K. Tiong, "CSFs in competitive tendering and negotiation model for BOT projects," Journal of Construction Engineering and Management, Vol. 122, pp. 205-211, 1996.

[14] L. Qiao, S.Q. Wang, R.L.K. Tiong, and T.S. Chan, "Framework for critical success factors of BOT projects in China," The Journal of Structured Finance, Vol. 7, No. 1, pp. 53-61, 2001.

[15] M. Ahadzi, and G. Bowles, "Public-private partnerships and contract negotiations: an empirical study,” Construction Management and Economics, Vol. 22, pp. 967-978, 2004. 
[16] T.M. Nisar, "Risk management in public-private partnership contracts," Public Organization Review, Vol. 7, pp. 1-19, 2007.

[17] M. Mustajab, Infrastructure Investment in Indonesia : Process and Impact, Rijksuniversiteit, Groningen, 2009.

[18] A.V. Thomas, S.N. Kalidindi, and K. Ananthanarayanan, "Risk perception analysis of BOT road project participants in India," Construction Management and Economics, Vol. 21, pp. 393-407, 2003.

[19] A.V. Thomas, S.N. Kalidindi, and L.S. Ganesh, "Modelling and assessment of critical risks in BOT road projects," Construction Management and Economics, Vol. 24, No. 4, pp. 407-424, 2006.

[20] J. Valentine, PPP in infrastructure - Best practices from International Experience and Applications for Thailand [Blog post], August 2008, [Online]. Available: http:// www.nesdb.go.th/ewt_w3c/ewt_dl_link.php?nid=2658

[21] B. Ashuri, M. ASCE, H. Kashani, K.R. Molenaar, S. Lee, and J. Lu, "Risk-neutral pricing approach for evaluating BOT highway projects with government minimum revenue guarantee options," Journal of Construction Engineering and Management, Vol.138, No. 4, pp. 545-557, 2012.

[22] A.P.C. Chan, P.T.I. Lam, D.W.M. Chan, E. Cheung, and Y. Ke, "Critical success factors for PPPs in infrastructure developments: Chinese perspective," Journal of Construction Engineering and Management, Vol. 136, No. 5, pp. 484-494, 2010.

[23] A. Dias, and P.G. Ioannou, "Company and project evaluation model for privately promoted infrastructure projects,” Journal of Construction Engineering and Management, Vol. 122, No. 1, pp. 71-82, 1996.

[24] W.R. Zhang, S.Q. Wang, ,R.L.K. Tiong, S.K. Ting, and D. Ashley, "Risk management of Shanghai's privately financed Yan'an Donglu tunnels," Engineering, Construction and Architectural Management, Vol. 5, No. 4, pp. 399-409, 1998.

[25] J.L. Ward, and J.M. Sussman, "Malaysian toll road public-private partnership program: Analysis and recommendations for policy improvements," Transportation Research Record: Journal of the Transportation Research Board, Vol. 1960, No. 1, 2006.

[26] N.T. Toan, and K. Ozawa, "Stakeholders' perception on risks of BOT infrastructure projects in Vietnam,” In CIB W107 Construction in Developing Countries International Symposium, Symposium conducted in Trinidad and Tobago, 2008.

[27] Y. Xu, J.F.Y. Yeung, A.P.C. Chan, D.W.M. Chan, S.Q. Wang, and Y. Ke, "Developing a risk assessment model for PPP projects in China - A fuzzy synthetic evaluation approach,” Automation in Construction, Vol. 19, No.7, pp. 929-943, 2010.

[28] N.A.A. Karim, "Risk allocation in Public Private Partnership (PPP) project: A review on risk factors," International Journal of Sustainable Construction Engineering \& Technology, Vol. 2, pp. 8-16, 2011.

[29] Y. Ke, S. Wang, A.P.C. Chan, and E. Cheung, "Understanding the risks in China's PPP projects: Ranking of their probability and consequence,” Engineering, Construction and Architectural Management, Vol. 18, pp. 481-496, 2011.

[30] B.G. Hwang, X. Zhao, and M.J.S. Gay, "Public private partnership projects in Singapore: Factors, critical risks and preferred risk allocation from the perspective of contractors," International Journal of Project Management, Vol. 31, pp. 424-433, 2013. 
[31] A.S. Ezeldin, and Y. Badran, "Risk Decision Support System for Public Private Partnership projects in Egypt," International Journal of Engineering and Innovative Technology, Vol. 3, No. 2, pp. 479-486, 2013.

[32] K.C. Iyer, and M. Sagheer, "Optimization of bid-winning potential and capital structure for build-operate-transfer road projects in India,” Journal of Management in Engineering, Vol. 28, No. 2, pp. 104-113, 2012.

[33] S.F. Slater, “Issues in conducting marketing strategy research,” Journal of Strategic Marketing, Vol. 3, No. 4, pp. 257-270, 1995.

[34] S. Ogunlana, and M.P. Abednego, "Case study II - Governance issues in the Yen Lenh bridge BOT project,” In Public-Private Partnership in Infrastructure Development: Case Studies from Asia and Europe, H.W. Alfen, ed.: Bauhaus-Universität Weimar, Weimar, Germany, pp. 63-88, 2009.

[35] N.D. Long, S. Ogunlana, T. Quang, and K.C. Lam, "Large construction projects in developing countries: A case study from Vietnam,” International Journal of Project Management, Vol. 22, No. 7, pp. 553-561, 2004.

[36] A. Pantelias, and Z. Zhang, "Methodological framework for evaluation of financial viability of public-private partnerships: Investment risk approach," Journal of Infrastructure Systems, Vol. 16, No. 4, pp. 241-250, 2010.

[37] J. Cohen, Statistical Power Analysis for the Behavioral Sciences, $2^{\text {nd }}$ Edition, Lawrence Erlbaum Associates, Hillsdale, New Jersey, United States, 1988. 